\title{
Observations of Segregation of Al in AlGaN Alloys
}

\author{
L. ChAnG ${ }^{1}$ ) (a), S. K. LAI (b), F. R. ChEn (b), and J. J. KAI (b) \\ (a) Department of Materials Science and Engineering, National Chiao Tung University, \\ Hsinchu, Taiwan
}

(b) Department of Engineering and System Science, National Tsing Hua University, Hsinchu, Taiwan

(Received June 26, 2001; accepted August 4, 2001)

Subject classification: 68.35.Gy; 68.37.Lp; 68.55.Ln; S7.14

\begin{abstract}
Transmission electron microscopy has been used to characterize $\mathrm{Al}$ segregation in $\mathrm{Al}_{0.1} \mathrm{Ga}_{0.9} \mathrm{~N}$ and $\mathrm{Al}_{0.3} \mathrm{Ga}_{0.7} \mathrm{~N}$ alloys grown by metal organic chemical vapor deposition on $6 \mathrm{H}-\mathrm{SiC}$. It has been found that an interlayer of AlGaN alloy with much higher Al content was formed at first, followed by normal growth of nominal composition of $\mathrm{AlGaN}$ alloy. In $\mathrm{Al}_{0.1} \mathrm{Ga}_{0.9} \mathrm{~N}$ and $\mathrm{Al}_{0.3} \mathrm{Ga}_{0.7} \mathrm{~N}$ films, dislocation lines were also found to have more $\mathrm{Al}$ segregated than those regions free of dislocations in the matrix. Furthermore, it shows that more $\mathrm{Al}$ atoms segregate to an edge dislocation than to a screw one.
\end{abstract}

Introduction $\mathrm{AlGaN}$ is a key material for optoelectronic and microwave device application [1,2]. The microstructures of AlGaN layers have been a subject of intensive research for the past few years [2-4]. AlGaN grown on $6 \mathrm{H}-\mathrm{SiC}$ substrate often contains a large number of dislocations (dislocation density $\sim 10^{9} \mathrm{~cm}^{-2}$ ) due to the lattice mismatch which depends on the Al composition in the alloys. A lower density of dislocations is necessary for high quality $\mathrm{GaN}$ films as the dislocations degrade the optoelectronic properties. Structural characteristics of dislocations in $\mathrm{GaN}$ related alloys with their effects on the optoelectronic properties have been characterized in the past [5-9]. However, composition variation within AlGaN ternary alloys has not been noticed. In this paper, we present evidence of $\mathrm{Al}$ segregation in the initial stage of deposition and around the dislocations in the grown films of $\mathrm{AlGaN}$ alloys based on the observations of transmission electron microscopy (TEM) with X-ray energy dispersive spectroscopy $(\mathrm{EDX})$ in a nanometer spatial resolution [10].

Experimental Conditions $400 \mathrm{~nm}$ thick $\mathrm{AlGaN}$ films in two different compositions were grown on 2 inch n-type $6 \mathrm{H}-\mathrm{SiC}(0001)$ substrates by metal organic chemical vapor deposition (MOCVD). The nominal concentrations of $\mathrm{Al}$ and $\mathrm{Ga}$ were deduced from double-crystal X-ray diffraction to be $\mathrm{Al}_{0.1} \mathrm{Ga}_{0.9} \mathrm{~N}$ and $\mathrm{Al}_{0.3} \mathrm{Ga}_{0.7} \mathrm{~N}$. Both the $\mathrm{AlGaN}$ films were doped with $\mathrm{Si}$ in the order of $10^{18} \mathrm{~cm}^{-3}$. The deposition temperatures were in the range of $1050-1250{ }^{\circ} \mathrm{C}$. The source materials used were triethylaluminium, triethylgallium, and $\mathrm{NH}_{3}$. The cross-sectional TEM specimens were prepared by a conventional sandwiched method consisting of gluing, mechanical thinning, and ion milling by Ar ion beam to perforation. TEM was carried out in a JEOL JEM 2010F microscope with a field-emission gun which can form an electron probe in a $0.5 \mathrm{~nm}$ diameter size. The operating voltage was set at $200 \mathrm{kV}$. The compositions were obtained by EDX from an Oxford Instrument EDX detector with an ultrathin window. All necessary pre-

\footnotetext{
1) Corresponding author; Phone: +886 3573 1615; Fax: +886 3572 4727; e-mail: lichang@cc.nctu.edu.tw
} 
cautions for the quantitative analysis of compositions had been taken before the acquisition of the spectra $[10,11]$. The beam broadening size is estimated to be less than $2 \mathrm{~nm}$. The concentrations were determined by assuming that the nitrogen concentration is constant, and the sum of $\mathrm{Ga}$ and $\mathrm{Al}$ are $100 \%$ in total.

Results and Discussion Figure $1^{2}$ ) shows the TEM images of $\mathrm{Al}_{0.1} \mathrm{Ga}_{0.9} \mathrm{~N}$ and $\mathrm{Al}_{0.3} \mathrm{Ga}_{0.7} \mathrm{~N}$ samples. At the interface with $\mathrm{SiC}$ substrate, it can be seen that there is an interlayer in dark contrast (bright field images of Figs. 1a and c), which has a different structure from the above AlGaN film as shown in the high-resolution images (Figs. 1b and d). EDX results (Table 1) reveal that the interlayer has a composition of $\mathrm{Al}_{0.4} \mathrm{Ga}_{0.6} \mathrm{~N}$ for deposition of the $\mathrm{Al}_{0.1} \mathrm{Ga}_{0.9} \mathrm{~N}$ alloy and $\mathrm{Al}_{0.8} \mathrm{Ga}_{0.2} \mathrm{~N}$ for that of the $\mathrm{Al}_{0.3} \mathrm{Ga}_{0.7} \mathrm{~N}$ alloy, respectively. Similar phenomena with Al-rich phases have been reported as a result of phase separation [12-14]. The formation of the interlayer suggests that nucleation on the substrates with higher concentration of $\mathrm{Al}$ may reduce lattice mismatch with $\mathrm{SiC}$. After the nucleation stage, the alloy growth proceeds with nominal composition. The formation of Al-rich interlayer may affect the dislocation density in the film grown because of their lattice mismatch between them.

The dislocations grown from the interface between $\mathrm{AlGaN}$ and $\mathrm{SiC}$ are clearly seen in Fig. 1. The mean dislocation spacing is about $100 \mathrm{~nm}$ (the density $\sim 9 \times 10^{9} \mathrm{~cm}^{-2}$ ) in

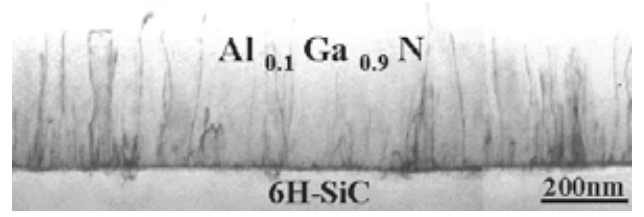

(a)

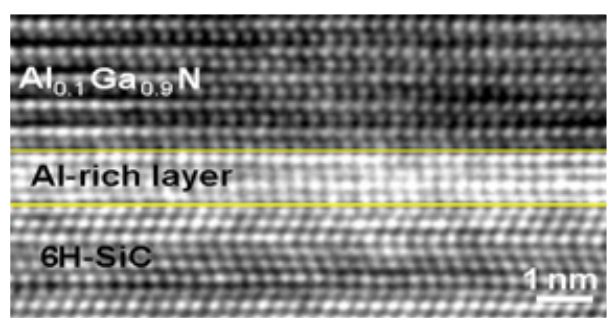

(b)

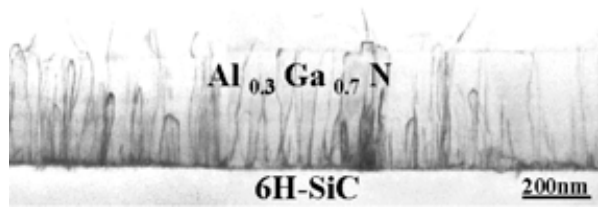

(c)

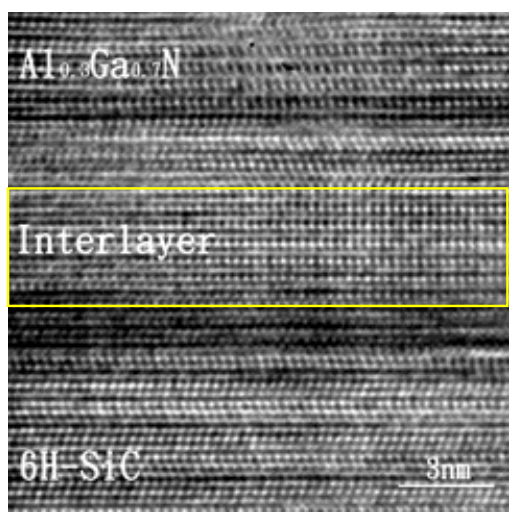

(d)

Fig. 1 (colour). Bright field and high-resolution TEM images of a), b) $\mathrm{Al}_{0.1} \mathrm{Ga}_{0.9} \mathrm{~N}$ and c), d) $\mathrm{Al}_{0.3} \mathrm{Ga}_{0.7} \mathrm{~N}$

2) Colour figure is published online (www.physica-status-solidi.com). 
Table 1

$\mathrm{Al}$ compositions (in at \%) measured from EDX. The bulk values were obtained from an electron beam in micron size. The rest values were obtained from nano beam measurements

\begin{tabular}{lcl}
\hline buffer layer & $\mathrm{Al}_{0.1} \mathrm{Ga}_{0.9} \mathrm{~N}$ & $\mathrm{Al}_{0.3} \mathrm{Ga}_{0.7} \mathrm{~N}$ \\
\hline bulk & 10.1 & 29.0 \\
interlayer & 46.9 & 79.3 \\
matrix & 9.6 & 21.0 \\
edge & 19.1 & 36.0 \\
screw & 12.6 & 30.9 \\
mixed & 14.2 & 33.8 \\
\hline
\end{tabular}

the $\mathrm{Al}_{0.1} \mathrm{Ga}_{0.9} \mathrm{~N}$ film and about $40 \mathrm{~nm}$ (the density $\sim 5 \times 10^{10} \mathrm{~cm}^{-2}$ ) in the $\mathrm{Al}_{0.3} \mathrm{Ga}_{0.7} \mathrm{~N}$ film. The edge type dislocations have the Burgers vector $1 / 3$ [11̄이, the screw [0001], and the mixed 1/3 [11̄3]. Detailed examination reveals that the dark line of contrast in the TEM images is mainly due to the strain field of a dislocation rather than a precipitate. EDX results from various areas probed by micron-size and nanometer-size electron beams are given in Table 1. The regions in the films probed by a large beam have a bulk composition close to the nominal value. However, the results from nanobeam probe show that the matrix free of dislocations has lower concentration of Al. In contrast, dislocations in both alloys have more Al segregated with. The segregation level of $\mathrm{Al}$ is highest at edge type dislocations, followed by the mixed type and the screw type ones. For the $\mathrm{Al}_{0.1} \mathrm{Ga}_{0.9} \mathrm{~N}$ case, the $\mathrm{Al}$ concentration at the edge dislocations is enriched about two times as high as that in the matrix. In $\mathrm{Al}_{0.3} \mathrm{Ga}_{0.7} \mathrm{~N}$, the $\mathrm{Al}$ enriched factor at the edge dislocations is about 1.5 times compared with the value in the matrix free of dislocations. The $\mathrm{Al}$ composition profiles across the different dislocations in the $\mathrm{Al}_{0.1} \mathrm{Ga}_{0.9} \mathrm{~N}$ alloy are demonstrated in Fig. 2. It is apparent that $\mathrm{Al}$ is enriched around the dislocation cores, but depleted at both sides in $2-3 \mathrm{~nm}$ regions. The depletion of $\mathrm{Al}$ to $4-8$ at\% is very significant in $\mathrm{Al}_{0.1} \mathrm{Ga}_{0.9} \mathrm{~N}$. Similar behaviors of $\mathrm{Al}$ segregation around dislocations are observed in the $\mathrm{Al}_{0.3} \mathrm{Ga}_{0.7} \mathrm{~N}$ alloy as well.

It is known that the $\mathrm{Al}$ atom has a smaller size than the $\mathrm{Ga}$ one. Therefore, $\mathrm{Al}$ segregation to the dislocations in AlGaN alloys is reasonable because the strain energy

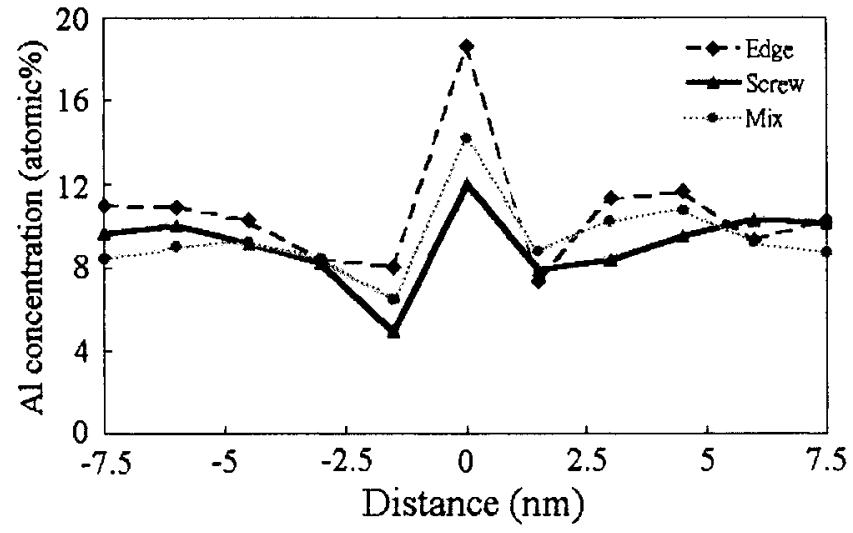

Fig. 2. Al concentration profiles across edge, screw, and mixed dislocations in $\mathrm{Al}_{0.1} \mathrm{Ga}_{0.9} \mathrm{~N}$ 
of dislocation can be reduced. It has been shown that the line energy of edge dislocation is higher than that of screw in $\mathrm{GaN}$ [15]. However, the enrichment of $\mathrm{Al}$ at an edge dislocation appears much stronger than at a screw dislocation from our EDX results. This may imply that the interaction energy of $\mathrm{Al}$ atoms with an edge dislocation is larger than with a screw one, probably due to the absence of elastic displacements parallel to the basal plane for the screw [16]. The reason about the Al depletion surrounding the dislocation cores is not clearly known. The presence of $\mathrm{Al}$ segregation around dislocations may pin the dislocation lines, which makes them difficult to move. As a result, the dislocation densities in AlGaN alloys may not be easily reduced. Thus, it is necessary to change the deposition conditions if a low dislocation density is desired for the AlGaN layers.

Conclusions $\mathrm{Al}$ segregation in $\mathrm{Al}_{0.1} \mathrm{Ga}_{0.9} \mathrm{~N}$ and $\mathrm{Al}_{0.3} \mathrm{Ga}_{0.7} \mathrm{~N}$ alloys grown on $6 \mathrm{H}-\mathrm{SiC}$ has been observed by TEM. An Al-rich interlayer with 47 and 80 at $\%$ was formed before normal growth of the film during deposition of $\mathrm{Al}_{0.1} \mathrm{Ga}_{0.9} \mathrm{~N}$ and $\mathrm{Al}_{0.3} \mathrm{Ga}_{0.7} \mathrm{~N}$, respectively. The $\mathrm{Al}$ concentration enriched at the dislocation core can be about two times as high as that in the matrix. The increase of Al concentration at the dislocations strongly depends on the dislocation type, which is the highest for the edge type and the next for the mixed type, followed by the screw type.

Acknowledgements We thank Dr. C. N. Huang of EpiStar Co., Taiwan, to provide the samples and for helpful discussion.

\section{References}

[1] O. AMBACher, J. Phys. D 31, 2653 (1998).

[2] J. A. Smart, A. T. Schremer, N. G. Weimann, O. Ambacher, L. F. Eastman, and J. R. Shealy, Appl. Phys. Lett. 75, 388 (1999).

[3] J. A. Smart, A. T. Schremer, N. G. Weimann, O. Ambacher, L. F. Eastman, and J. R. Shealy, Appl. Phys. Lett. 75, 388 (1999).

[4] G. Steude, T. Christmann, B. K. Meyer, A. Goeldner, A. Hoffmann, F. Bertram, J. Christen, H. AMANo, and I. AKASAKI, MRS Internet J. Nitride Semicond. Res. 4S1, G3.26 (1999).

[5] D. J. Smith, D. Chandrasekhar, B. Sverdlov, A. Botchkarev, A. Salvador, and H. Morkoç, Appl. Phys. Lett. 67, 1830 (1995).

[6] F. R. Chien, X. J. Ning, S. Stemmer, P. Pirouz, M. D. Bremser, and R. F. Davis, Appl. Phys. Lett. 68, 2678 (1996).

[7] F. A. Ponce, D. Cherns, W. T. Young, and J. W. Steeds, Appl. Phys. Lett. 69, 770 (1996).

[8] Y. Xin, S. J. Pennycook, N. D. Browning, P. D. Nelist, S. Sivannthan, F. Omnes, B. Beaumont, J.-P. FAurie, and P. GibarT, Appl. Phys. Lett. 72, 2680 (1998).

[9] J. S. SPECK and S. J. RosNer, Physica B 274, 24 (1999).

[10] R. F. EgERTon, Electron Energy-Loss Spectroscopy in the Electron Microscope, 2nd ed., Plenum Press, New York 1996.

[11] J. I. Goldstein, D. B. Williams, and G. Cliff, in: Principles of Analytical Electron Microscopy, Eds. D. C. Joy, A. D. Romig, JR., and J. I. Goldstein, Plenum Press, New York 1986 (pp. 155217).

[12] B. Neubauer, A. Rosenauer, D. Gerthisen, O. Ambacher, and M. Stutzmann, Appl. Phys. Lett. 73, 930 (1998).

[13] A. Cremades, M. Albrecht, J. Krinke, R. Dimitrov, M. Stutzmann, and H. P. Strunk, J. Appl. Phys. 87, 2357 (2000).

[14] P. Vennegues and H. Lahreche, Appl. Phys. Lett. 77, 4310 (2000).

[15] J. Elsner, R. Jones, P. K. Sitch, V. D. Porezag, M. Elstner, Th. Frauenheim, M. I. Heggie, S. OberG, and P. R. BRIDDON, Phys. Rev. Lett 79, 3672 (1997).

[16] X. H. Wu, L. M. Brown, D. Kapolnek, S. Keller, B. Keller, S. P. DenBaars, and J. S. Speck, J. Appl. Phys. 80, 3228 (1996). 